\title{
Platelet Profile as Prognostic Factor in Critically ill Children
}

\author{
Gema Nazri Yanni*, Rina Amalia C. Saragih \\ Department of Child Health, Faculty of Medicine, Universitas Sumatera Utara, Medan, Indonesia
}

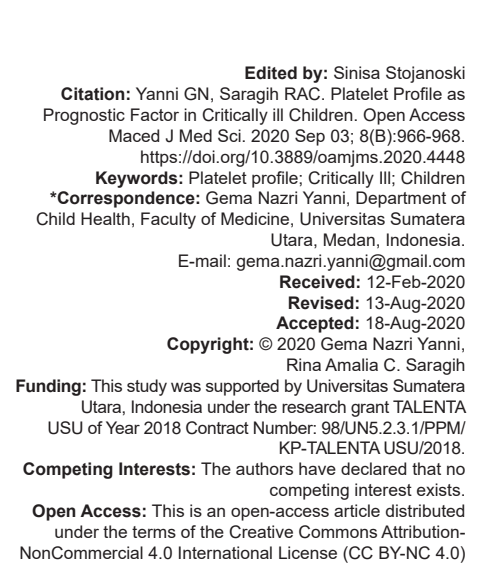

Introduction

Studies had indicated that inflammation associated endothelial dysfunction is one of the causes of organ failure which is related to platelet activation and consumption. According to these findings, changes in platelet count are closely associated with the prognosis of critically ill patients [1]. The platelet profile may reflect the platelet function better than the platelet count itself [2]. The platelet profile includes mean platelet volume (MPV), platelet distribution width (platelet distribution width [PDW]), and plateletcrit (PCT). They are part of routine hematologic parameters examined in routine complete blood count; thus, it is low cost and very feasible in daily clinical practice; however, their use and application in critically ill children are still limited [3].

The association between changes in MPV level and patient's morbidity and mortality in various diseases has been reported in several adult studies [4], [5], [6], [7]. However, studies in children population are still limited. Only a few studies had revealed the association between MPV and early diagnosis [8], [9], [10], [11] or mortality of sepsis in the neonatal period [12], [13]. We used pediatric logistic organ dysfunction-2 (PELOD-2) score and mortality as prognostic in this study.
This prospective cohort study on critically ill children was conducted between May 2018 and July 2018. Inclusion criteria were children aged 1 month18 years old, admitted to the pediatric intensive care unit (PICU) Haji Adam Malik Hospital and Universitas Sumatera Utara Hospital.

Patients with malignancy, idiopathic thrombocytopenic purpura, immunodeficiency, history of using chemotherapy agent, and refused for laboratory test were excluded from the study. Subjects were recruited consecutively.

We examined the platelet profile (platelet count, PCT, MPV, and PDW) and PELOD-2 score on the $1^{\text {st }}$ and $3^{\text {rd }}$ day of PICU admission. Data were analyzed using SPSS version 20. This study was approved by the Health Research Ethical Committee, Medical Faculty, Universitas Sumatera Utara with No.206/TGL/KEPK FK USU-RSUP HAM/2018.

\section{Results}

From this study, of all 83 patients recruited, sepsis was found in 43 subjects. Mortality was found in 
$19(25 \%)$ patients. The baseline characteristics of study subjects are shown in Table 1.

Table 1: Subject characteristics

\begin{tabular}{ll}
\hline Characteristic & $\mathrm{n}=83$ \\
\hline Age (months); median (min-max) & $6(1-17)$ \\
Gender; $\mathrm{n}(\%)$ & \\
$\quad$ Boys & $44(53)$ \\
$\quad$ Girls & $39(47)$ \\
Nutritional status; $\mathrm{n}(\%)$ & \\
$\quad$ Severe malnutrition & $20(23.8)$ \\
Moderate malnutrition & $11(13.1)$ \\
Normal & $51(61.4)$ \\
Overweight & $1(1.2)$ \\
Mortality; $\mathrm{n}(\%)$ & $19(25)$ \\
Sepsis & $43(51.8)$ \\
Platelet count/mm ${ }^{3}$, mean (SD) & $327,200(169,931)$ \\
MPV, pg; median (min-max) & $9.2(7.9-1.6)$ \\
PCT, pg; median (min-max) & $0.32(0.07-1.4)$ \\
PDW, pg; median (min-max) & $9.7(7-15.7)$ \\
PELOD-2 score; median (min-max) & $3.5(0-19)$ \\
\hline PELOD-2: Pediatric logistic organ dysfunction-2, PWD: Platelet distribution width, PCT: Plateletcrit,
\end{tabular}

MPV: Mean platelet volume.

Table 2 shows the association between each platelet profile and mortality. Abnormal platelet counts on the $1^{\text {st }}$ day of PICU admission were significantly associated with mortality $(p=0.024)$. We also found a statistically significant association between PDW on the $3^{\text {rd }}$ day of PICU admission and mortality (0.018). Neither MPV nor PCT showed any statistically significant association with mortality in this study.

Table 2: Association between each platelet indices and mortality on $1^{\text {st }}$ and $3^{\text {rd }}$ days of PICU admission

\begin{tabular}{|c|c|c|c|}
\hline Platelet Indices & Mortality (n\%) & Survival (n\%) & $P$ \\
\hline \multicolumn{4}{|l|}{ Day 1} \\
\hline \multicolumn{4}{|l|}{ Platelet, $\mathrm{mm}^{3}$} \\
\hline Normal & 8 & 46 & \multirow[t]{2}{*}{0.024} \\
\hline Abnormal & 11 & 18 & \\
\hline \multicolumn{4}{|l|}{ MPV } \\
\hline Normal & 10 & 28 & \multirow[t]{2}{*}{0.237} \\
\hline Abnormal & 6 & 33 & \\
\hline \multicolumn{4}{|l|}{ PCT } \\
\hline Normal & 11 & 49 & \multirow[t]{2}{*}{0.297} \\
\hline Abnormal & 3 & 6 & \\
\hline \multicolumn{4}{|l|}{ PDW } \\
\hline Normal & 6 & 28 & \multirow[t]{2}{*}{0.512} \\
\hline Abnormal & 10 & 32 & \\
\hline \multicolumn{4}{|l|}{ Day 3} \\
\hline \multicolumn{4}{|l|}{ Platelet, $\mathrm{mm}^{3}$} \\
\hline Normal & 7 & 31 & \multirow[t]{2}{*}{0.921} \\
\hline Abnormal & 6 & 25 & \\
\hline \multicolumn{4}{|l|}{ MPV } \\
\hline Normal & 4 & 25 & \multirow[t]{2}{*}{0.412} \\
\hline Abnormal & 7 & 25 & \\
\hline \multicolumn{4}{|l|}{ PCT } \\
\hline Normal & 9 & 40 & \multirow[t]{2}{*}{0.929} \\
\hline Abnormal & 1 & 4 & \\
\hline \multicolumn{4}{|l|}{ PDW } \\
\hline Normal & 10 & 26 & \multirow[t]{2}{*}{0.018} \\
\hline Abnormal & 1 & 24 & \\
\hline
\end{tabular}

Table 3 shows that there was no correlation between MPV, PDW, PCT, and Platelet with PELOD-2 score. However, it turns out that the difference of MPV $(\triangle \mathrm{MPV})$ and PELOD-2 score ( $\triangle \mathrm{PELOD}-2)$ at the $1^{\text {st }}$ and $3^{\text {rd }}$ day has a significant correlation as describe on Graphic 1 ( $r=0.646, p<0.0001)$.

Table 3: Correlation between platelet profile and PELOD-2 score

\begin{tabular}{|c|c|c|c|c|c|}
\hline \multirow[t]{2}{*}{ Platelet profile } & \multicolumn{2}{|c|}{ PELOD-2 score D1 } & \multirow[t]{2}{*}{ Platelet profile } & \multicolumn{2}{|c|}{ PELOD-2 score D3 } \\
\hline & $\mathrm{R}$ & $p$ & & $\mathrm{R}$ & $p$ \\
\hline MPV & 0.183 & 0.258 & MPV & -0.027 & 0.878 \\
\hline PDW & 0.031 & 0.848 & PDW & -0.023 & 0.899 \\
\hline PCT & -0.129 & 0.445 & PCT & -0.177 & 0.340 \\
\hline Platelet & -0.332 & 0.03 & Platelet & -0.238 & 0.151 \\
\hline
\end{tabular}

MPV: Mean platelet volume.

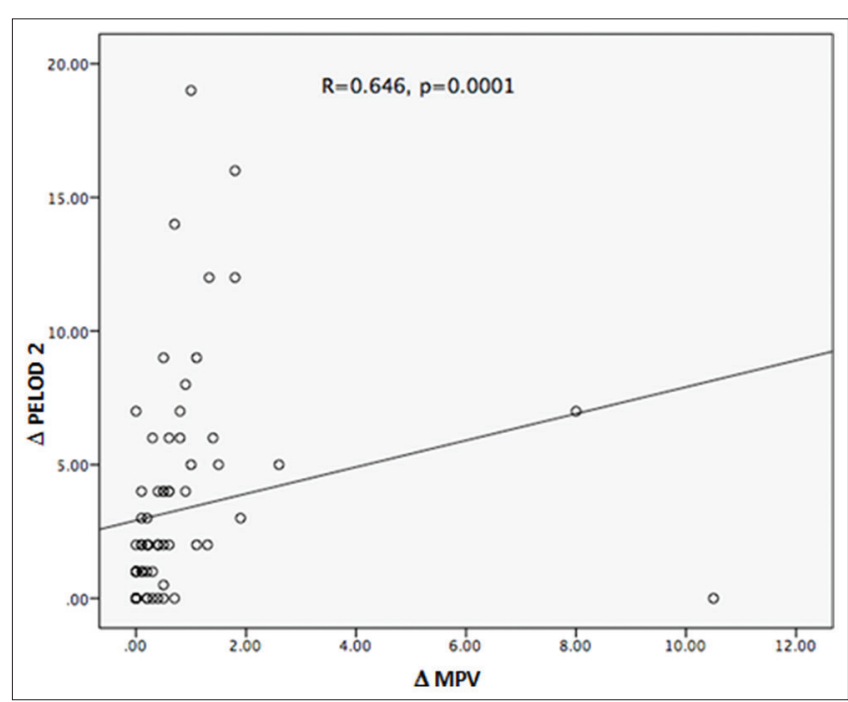

Graphic 1: Correlation between $\Delta$ mean platelet volume and $\Delta$ pediatric logistic organ dysfunction-2

\section{Discussion}

There is growing evidence to show that MPV, PDW, and red blood cell distribution width are associated with mortality in adult population. Gao et al. show that PDW has increasing trends, while PCT and platelet count decreased in the non-survivor group and compared with other more usual septic shock prognostic markers, MPV is also second only to lactate for the highest area under the curve. Tajarernmuang et al. also stated that MPV was observed to be significantly higher in non-survivor groups after the $3^{\text {rd }}$ day of admission [2], [3]. In this study, we found a statistically significant association between platelet on $1^{\text {st }}$ day and PDW on the $3^{\text {rd }}$ day of PICU admission and mortality, while neither MPV nor PCT showed any statistically significant association with mortality in this study. Mean platelet count is almost entirely normal in the survival group on $1^{\text {st }}$ day and then becomes abnormal on day 3 , its likely due to the different course of the disease and different degrees of inflammation.

Studies on clinical values of platelet profile in critically ill children are still limited. A retrospective study by $Y e$ et al. on critically ill children receiving mechanical ventilation reported that there were significant associations between PCT and PDW with mortality. These studies also demonstrated that patients with a low platelet count and high MPV and PDW survived for a shorter time than those with normal platelet indices; thus, platelet indices were proposed as a novel prognostic indicator in critically ill patients [14]. Similarly, Aydemir et al. show that increase in MPV values was statistically significant for the first 3 days of sepsis [7]. A systematic review and meta-analyses by Tajarernmuang et al. also show that initial values of MPV might not be used as 
a prognostic marker of mortality in critically ill patients, while subsequent values of MPV after the $3^{\text {rd }}$ day might be useful [2]. This study is consistent with our result that shows a significant correlation between the difference of MPV ( $\triangle$ MPV) and PELOD-2 score ( $\triangle$ PELOD-2).

The course of an inflammatory condition is also associated with an increased percentage of large platelets, probably due to intracellular synthesis of procoagulatory and proinflammatory factors, degranulation of granules, and initiation of the platelet pool stored in the spleen [15]. Simultaneously, these cells rapidly migrate to the site of inflammation, where they undergo activation and use [16]. This seems to explain the drop in MPV in patients with ongoing inflammation [17].

In the clinical setting, platelet profile and PELOD-2 score should be examined serially on the $1^{\text {st }}$ day as basic data and followed by the $3^{\text {rd }}$ day, so we can assess the prognostic of the critically ill patient. This suggested that serial measurements had more valuable predictive value than examination on admission only.

\section{Conclusion}

We found that platelet on $1^{\text {st }}$ day and PDW on the $3^{\text {rd }}$ day of PICU admission had a significant association with mortality. There was no correlation between platelet profile and PELOD-2 score, but the difference of MPV ( $\triangle \mathrm{MPV})$ and PELOD-2 score $(\Delta$ PELOD-2) between the examinations has a significant correlation. Subsequent values of the platelet profile might had more valuable predictive value than one initial examination. Further studies analyzing its usefulness in critically ill children are still needed.

\section{References}

1. Aird WC. The role of the endothelium in severe sepsis and multiple organ dysfunction syndrome. Blood. 2003;101(10):376577. https://doi.org/10.1182/blood-2002-06-1887 PMid:12543869

2. Tajarernmuang P, Phrommintikul A, Limsukon A, Pothirat C, Chittawatanarat $\mathrm{K}$. The role of mean platelet volume as a predictor of mortality in critically III patients: A systematic review and meta-analysis. Crit Care Res Pract. 2016;2016:4370834. https://doi.org/10.1155/2016/4370834

PMid:269665743.

3. Gao Y, Li Y, Yu X, Guo S, Ji X, Sun T, et al. The impact of various platelet indices as prognostic markers of septic shock. PLoS One. 2014;9(8):e103761. https://doi.org/10.1371/journal. pone.0103761

PMid:25118886

4. Chu SG, Becker RC, Berger PB, Bhatt DL, Eikelboom JW, Konkle $\mathrm{B}$, et al. Mean platelet volume as a predictor of cardiovascular risk: A systematic review and metaanalysis. J Thromb Haemost. 2010;8(1):148-56. https://doi. org/10.1111/j.1538-7836.2009.03584.x

PMid:19691485

5. Cho SY, Jeon YL, Choi SK, Suh JT, Lee HJ, Park TS. Mean platelet volume in Korean patients with acute ischemic stroke: A gender difference. Platelets. 2013;24(1):75-6. https://doi.org/10 .3109/09537104.2012.658109

PMid:22385189

6. Altintoprak F, Arslan Y, Yalkin O, Uzunoglu Y, Ozkan OV. Mean platelet volume as a potential prognostic marker in patients with acute mesenteric ischemia-retrospective study. World J Emerg Surg. 2013;8(1):49. https://doi.org/10.1186/1749-7922-8-49 PMid:24274639

7. Aydemir H, Piskin N, Akduman D, Kokturk F, Aktas E. Platelet and mean platelet volume kinetics in adult patients with sepsis. Platelets. 2015;26(4):331-5. https://doi.org/10.3109/09537104. 2012.701027

PMid:22731700

8. Guida JD, Kunig AM, Leef KH, McKenzie SE, Paul DA. Platelet count and sepsis in very low birth weight neonates: Is there an organism-specific response? Pediatrics. 2003;111(1):1411-5. https://doi.org/10.1542/peds.111.6.1411

PMid:12777561

9. Akarsu S, Taskin E, Kilic M, Ozdiller S, Gurgoze MK, Yilmaz E, et al. The effects of different infectious organisms on platelet counts and platelet indices in neonates with sepsis: Is there an organism-specific response? J Trop Pediatr. 2005;51(6):388-91. https://doi.org/10.1093/tropej/fmi031

PMid: 16126807

10. Aksoy HT, Eras Z, Guzoglu N, Canpolat FE, Dilmen U. Mean platelet volume is not associated with bacterial sepsis in newborns. Int J Infect Dis. 2013;17(12):e1263. https://doi. org/10.1016/j.ijid.2013.05.010 PMid:23856507

11. Aydin B, Dilli D, Zenciroğlu A, Karadağ N, Beken S, Okumuş N Mean platelet volume and uric acid levels in neonatal sepsis: Authors' reply. Indian J Pediatr. 2014;81(2):101. https://doi. org/10.1007/s12098-014-1417-4 PMid:24974966

12. Ahmad MS, Waheed A. Platelet counts, MPV and PDW in culture proven and probable neonatal sepsis and association of platelet counts with mortality rate. J Coll Physicians Surg Pak. 2014;24(5):340-4. PMid:24848393

13. Tayman C, Tonbul A, Akca H, Bilici M. Mean platelet volume (MPV) may simply predict the severity of sepsis in preterm infants. Clin Lab. 2014;60(7):1193-200. https://doi.org/10.7754/ clin.lab.2013.130501 PMid:25134389

14. Ye S, Zhang Y, Zhang C, Xu D. Are platelet volume indices related to mortality in hospitalized children on mechanical ventilation? J Int Med Res. 2018;46(3):1197-208. https://doi. org/10.1177/0300060517737211 PMid:29322854

15. Schwertz H, Koster S, Kahretal WH. Anucleate platelets generate progeny. Blood. 2010;115(18):3801-9. PMid:20086251

16. Kamath S, Blann AD, Lip GY. Platelet activation: Assessment and quantification. Eur Heart J. 2001;22(17):1561-71. PMid:11492985

17. Afsar $\mathrm{N}$, Afroze IA, Tahniath $\mathrm{H}, \mathrm{Abid} \mathrm{Z}$. Role of mean platelet volume as an adjunct in evaluation of acute inflammation. Ann Pathol Lab Med. 2017;4(4):466-9. https://doi.org/10.21276/apalm.1486 